\title{
DEMARCATION DISPUTES IN BRITISH SHIPBUILDING BEFORE I9I4
}

Matters of labour organisation and control are clearly related to the progress of mechanisation. Economic growth results from increases in productivity brought about by management's combination of trained men and "skillful" machines in productive work. In isolation neither management, labour, nor capital can in themselves achieve sustained growth in the output of goods and services; the efficient co-ordination of a trained and disciplined workforce with equipment designed to perform specific activities is always required. In a period of changing technology such as the nineteenth century, however, the proper co-ordination may be difficult to achieve because the introduction of workers with new talents or machines which can perform multiple functions is apt to disturb existing work routines, upset prevailing cost relationships, and force management to reorganise entire sections of the productive process. This is particularly true if the various functions performed by new types of machinery have hitherto been assigned to more than one man or group of men.

Ames and Rosenberg point out that in a pre-industrial economy of unspecialised (skilled) labour and specialised machines, the boundaries between firms in a process were usually at the boundaries between skilled trades. In modern industry, on the other hand, where labour is specialised and machines unspecialised, firm boundaries are determined by the boundaries between machines. ${ }^{1}$ The nineteenth century was a period of transition, in which there might have been significant

1 Edward Ames and Nathan Rosenberg, "The Progressive Division and Specialization of Industries", in: Journal of Development Studies, I (1964-65), pp. 371-72. The more specialised a man, the fewer tasks or activities he can perform. Hence skilled workers, who perform many tasks, are relatively unspecialised, while machine operatives, who perform only one, are highly specialised. Similarly, the fewer tasks a machine can perform, the more highly specialised it is. Particularly in this century, increased division of labour has taken the form of introducing less specialised machines, which allow one specialised worker to perform as many tasks as several workers using more highly specialised equipment. Ibid., pp. 367-70. 
proportions of both specialised and unspecialised men and machines within a single industry. In such circumstances, boundaries between activities within and between firms might well have been extremely difficult for management to define, even if the potential gains from increased division of labour were very great. To produce a solution, arbitrary decisions might be made on the demarcations between different groups of workers or machines. These could then affect the continuing development of the industry by creating the "format" or framework in which future technical and organizational changes would be undertaken. To the extent that this "format" led to rigidities within a firm or industry which limited the capacity of management to reorganize effectively, the potential productivity of new talents and machinery might not be fully realised and the rate of technological or economic progress reduced. As a consequence, the competitive ability of the firm or industry could be jeopardised.

The British engineering industry in the first half of the nineteenth century provides an excellent example of the way in which a "format" of labour force distribution suitable for one set of technological conditions can create conflicts during a period of technological change. Early engineering workers were millwrights, pre-industrial craftsmen whose high level of manual skills was necessary to achieve a satisfactory quality of output. From the 1830's, however, the development of machine tools made it possible for engineering firms to rely increasingly on semi-skilled or unskilled labourers, who now competed for jobs which were formerly in the province of the millwright engineers. Especially in periods of recession, the millwrights found it more difficult than formerly to gain employment. On the other hand, the need for all types of skilled labour had not been eliminated, and so at mid-century remnants of the old pre-industrial system of organisation co-existed uneasily in the same works with the more modern machine-based system. In order to regain the job security and prestige which they had once enjoyed, in 1850-51 the local societies of millwrights banded together to form the Amalgamated Society of Engineers. The following year, the ASE attempted to ban piece work and systematic overtime, two of the consequences of increased mechanisation which the engineers found to be most damaging to their cause. The Society was forced to back down following the engineering lock-out of $1852,{ }^{1}$ but it is clear that had the millwrights achieved their demands the incentive to mechanise, and hence the rate of technological change, would have been reduced.

1 Keith Burgess, "Technological Change and the 1852 Lock-out in the British Engineering Industry", in: International Review of Social History, XIV (1969), pp. 215-36. 
One of the central problems confronting the management of British shipyards before 1914 was also to identify the proper co-ordination among men and equipment. Management had first to determine that enough (but not too many) men with appropriate skills were available, and then to deploy them in relation to each other and to the available machinery so that ships could be built in as efficient and profitable a manner as possible in the circumstances. To be sure, this is virtually a definition of the managerial function in any era, but the difficulty was intensified by the increasing complexity of shipping technology in the course of the nineteenth century. Vessels came to be powered by steam; engines changed from simple to compound and triple- and quadruple-expansion models, with corresponding changes in indicated horsepower and fuel consumption. In the years immediately preceding the First World War, turbines came into use and oil began to replace coal as a fuel. In this same period, iron and steel replaced wood in the construction of ships' hulls and the trend towards ever-larger vessels which had begun earlier in the century continued apace. Changes in the demand for shipping services led to the introduction of new classes of vessels. By 1914 luxury passenger liners and steam freighters dominated merchant fleets. Both had specialised shipboard appliances to increase comfort and safety, and facilitate the handling of large cargoes. To build these new types of vessels, shipyard owners and managers were obliged both to increase the scale of their operations and to introduce new skills, materials and machinery. In the course of this development, the shipbuilding industry was transformed from a group of small craft-oriented construction firms into one of highlycapitalised large-scale concerns, which undertook a wide variety of manufacturing and constructional operations.

The division of labour in the firm was intensified and modern mechanical equipment incorporated. But, owing to the nature of the shipbuilding industry, which for the most part produced a large, custom-made commodity and expanded through the addition of crafts new to shipbuilding rather than through subdivision of traditional ones, management found it difficult to make the adjustments in labour-force organisation which were necessary to take full advantage of technological improvements. The strength of a traditional tradeunion structure based on the division of skills insured that the industry continued to be stratified along craft lines at a time when mechanisation was increasingly destroying the very barriers which had divided one trade from another. As a result, the shipbuilding industry became notorious for its demarcation or jurisdictional disputes, in which crafts fought each other over the allocation of work.

Labour historians have often accepted the argument that de- 
marcation disputes were especially common because shipbuilding "from the wooden sailing ship to the steel steamship had undergone in a short span of years a thorough-going technical revolution without a corresponding regrouping of unions". ${ }^{1}$ This is to misunderstand both the nature and the development of the industry. The purpose of this article is to show that the multiplicity of crafts and unions active in the shipyards was the result of the technical revolution, and not an anachronism which had somehow survived despite the good sense of the workers and their employers. It survived because, although the proportion of unskilled and semi-skilled machine operatives did increase, shipbuilding was still in 1914 a construction industry which required men with varied skills of a high level, and was not susceptible to many of the techniques of mass production. The division of unions along craft lines did correspond to the actual functional division of the labour force; the introduction of unions enrolling members from all sectors of the workforce would not have been as appropriate as it was in other branches of heavy industry in which the workforce was predominantly unskilled and labourers were largely interchangeable. While subsequent changes in the technology of shipbuilding tended to blur the boundaries between trades and resulted in inter-union strife, the stratification of the industry along craft lines remained on balance the most appropriate way of organizing the highly-skilled workforce and its trade unions.

In the first half of the nineteenth century, when the wooden shipbuilding was mainly concentrated in large English ports such as London, Liverpool and Hull, yard owners often had very little control over their workforces. The men engaged in building and repairing wooden vessels were overwhelmingly skilled tradesmen, primarily shipwrights, who even before the repeal of the Combination Acts in 1824 had formed illegal societies. The first important permanent group, however, was the Shipwrights Provident Union of the Port

1 E. H. Phelps Brown, The Growth of British Industrial Relations (London, 1959), p. 236. As early as 1897, Sidney and Beatrice Webb chose shipbuilding as their primary example of inter-union warfare in their discussion of "The Right to a Trade". Industrial Democracy (London, 1897), pp. 508-27. More recent treatments of demarcation disputes in shipbuilding include Geoffrey Roberts, Demarcation Rules in Shipbuilding and Shiprepairing [University of Cambridge Department of Applied Economics, Occasional Paper No 14] (Cambridge, 1967), ch. 2; and R. K. Brown, P. Brannen, J. M. Cousins and M. L. Samphier, "The Contours of Solidarity: Social Stratification and Industrial Relations in Shipbuilding", in: British Journal of Industrial Relations, X (1972), pp. 12-41. 
of London, which was apparently formed at the inspiration of a similar group on the Tyne to enforce a piece-rate book and drive out unqualified jobbers. In subsequent years, unions of varying importance were founded in a number of ports. They were generally strong enough to force a closed shop and to demand union membership and apprenticeship for foremen. One of their main preoccupations was to restrict competition by eliminating migration. The outcome was an era of low geographic mobility in which, in the words of the Webbs, "the shipwrights had a local club in every port, each of which strove with might and main to exclude from any chance of work in the port all but men who had learnt their trade within its bounds". Until the possibilities of migration and wage competition grew, the shipwrights' societies remained narrow and restrictive. ${ }^{1}$

Although practices varied from port to port, the wooden shipbuilding industry was organised in much the same way as house building or other sectors of construction. In London, for example, yard owners, themselves master shipwrights, acted as general contractors who negotiated with customers and supplied facilities and materials in return for a percentage of the cost of the work performed. The shipwrights, who provided their own tools, then acted as subcontractors. In many yards, they grouped themselves into "gangs" or "teams" which were hired by the job for a fixed price based on an estimate of how much they would have received for the same amount of work if paid individually by the day. The price of each job was determined separately, and as the work progressed yard owners advanced wages depending on the proportion of the job completed or the time elapsed. If any money remained at the end, it was paid in a lump sum, which the gang members divided among themselves. It was essentially a contract system of piece wages, which encouraged the shipwrights to complete the work more quickly than they would have done if hired and paid by the day or week. Particularly after 1824, when the Shipwrights Provident Union of the Port of London was founded, master contractors were unable to dictate the membership of the gangs, and in some cases apprentices were bound to gang members rather than to the yard owners. ${ }^{2}$ In some areas, yard owners had even less power to regulate their "workers". At Liverpool, building

1 Evidence before the Select Committee on Combination Laws, 1825, pp. 250-75; Sidney Pollard, "The Decline of Shipbuilding on the Thames", in: Economic History Review, New Series, III (1950), pp. 74-75; Webb, Industrial Democracy, pp. 73-74.

2 Evidence before the Select Committee on Combination Laws, 1825, pp. 192-94, 217, 222; evidence before the Royal Commission on Trade Unions, 1867-68, qq. 16,591-608. 
was performed for day wages, but in the important repair sector of the industry shipwrights were paid directly by shipowners and could refuse to follow the orders of the yard masters. ${ }^{1}$

As the number of trades and workers grew and yards became more heavily capitalised with the advent of iron steamships, the contracting builders found subcontracting to be increasingly intolerable. The complexities of negotiating with each trade made it difficult to arrive at prices which were satisfactory to buyers, and placed the fate of the builders' large fixed investments beyond their control. In some cases, helpers were paid by and responsible to skilled tradesmen rather than to yard owner-builders. The latter could not be sure of how much their employees were receiving, and were sometimes plagued by friction among workers created by unequal wages for the same tasks. Subcontracting persisted down into the 1860's on the Thames, where in at least one yard even riveters were covered under contracts granted to shipwrights. It never became firmly established in the newer iron shipbuilding centres on the North-East coast and the Clyde, however, where most unions objected to piece wages and to paying their assistants themselves. As the newer builders gained the ability to pay the entire labour force through the central office, the older contract system eventually disappeared. ${ }^{2}$

Only one major group, the members of the United Society of Boilermakers and Iron and Steel Ship Builders, continued to work on a variation of the gang and contract system throughout the shipbuilding industry. Platers and angle-iron smiths worked in teams with one skilled worker and six or eight helpers. As the boilermakers were paid by the piece but the helpers received day wages, the skilled men were able to sweat the unskilled by forcing them to work at a maximum pace for no extra pay beyond an occasional bonus. Conflicts arose between the platers and angle-iron smiths and the employers over control of the helpers, but the boilermakers no longer wanted to pay

1 Evidence before the Select Committee on Artizans and Machinery, 1824, pp. $190,192-93$.

2 Evidence before the Royal Commission on Trade Unions, ibid., qq. 16,616-30, $16,711-12,17,050-66,17,076-95,17,131,17,193,17,226,17,335,17,642$; evidence before the Royal Commission on Labour, 1892, Group A [Cd 6894] (1893-94), qq. 20,798-800; S. Pollard, "The Economic History of British Shipbuilding, 1870-1914" (unpublished Ph.D. thesis, University of London, 1950), pp. 142-43. Pollard contends that the continuance of the contract system on the Thames was one of the primary reasons for the shift of the industry to the North-East coast of England and to Scotland. "The Decline of Shipbuilding on the Thames", loc. cit., pp. 72-74. However, since 1945 a revised version of the contract system, under which the members of a trade, although employees of the builder, are paid a fixed price for all of the work on a ship, has been introduced. R. K. Brown et al., loc. cit., pp. 19-20. 
the helpers themselves and generally acceded to the employers' demands to pay them directly through the central office. From the standpoint of the Boilermakers' Society, the arrangement worked well: by 1906 shipyard platers were probably the most highly-paid trade in all British industry. ${ }^{1}$

Greater mechanisation and capitalisation increased central authority, but the demise of the contract system did not bring an end to the organisation of yards along craft lines. Almost all major innovations in nineteenth-century shipping technology, including the adoption of iron and steel for hull and frame construction, steam power, electrification and modern plumbing equipment, were similar to changes which had occured earlier in other manufacturing and construction fields. Thus it was possible for yard owners to expand their labour force by taking on men with skills which had already been developed elsewhere, and which required only minor adaptations to fit the conditions of shipbuilding. The division of labour was largely a matter of adding new men to perform the activities which changes in shipping technology demanded rather than of splitting up the tasks of the trades traditionally associated with shipbuilding.

Because of their refusal to handle iron in the early years, shipwrights were deprived of their main activity of constructing hulls when iron ships came to predominate during the 1850's. Platers, angle-iron smiths, riveters, drillers and caulkers were hired from engineering shops, and unskilled labourers from within shipbuilding were trained to perform metal work. By the time it was obvious that most of the larger ships were to be built of iron, the metal trades were firmly established and the shipwrights were unable to regain their position. They were restricted to drawing the lines of hulls, shaping the frames and launching the vessels, as well as performing heavy timber work on board. They also supplied moulds for the components, plates and bars, which iron workers then shaped and assembled. $^{2}$

1 Evidence before the Royal Commission on Labour, ibid., qq. 20,448-56, $20,511-29,20,561,20,608-20,20,632,20,668-71,20,775-800,20,853,20,995-99$; J. Lynch, "Skilled and Unskilled Labour in the Shipbuilding Trade", in: Report of the Industrial Remuneration Conference (London, 1885), pp. 114-19; E. J. Hobsbawm, "The Labour Aristocracy in Nineteenth Century Britain", in Labouring Men (New York, 1964), table V, p. 288.

a Pollard, "The Economic History of British Shipbuilding", op. cit., pp. 141-42; Sir Westcott Abell, The Shipwright's Trade (Cambridge, 1948), p. 185; evidence before the Royal Commission on Labour, ibid., qq. 21,400-01. 
Other skills were brought in as shipping technology grew in complexity and many firms began to build their own marine engines. Although some workers, such as riveters, became specialised to work in shipbuilding, most of the ninety crafts represented in 1914 were identical to those needed in machine tool making, light and heavy metal fabrication, engine shops, or general construction. Only the trades which evolved from the shipwrights were peculiar to shipbuilding, and they were responsible for perhaps ten per cent of the work on iron or steel vessels. ${ }^{1}$

The origins of the industry in a skilled craft and the way in which it evolved through an accretion of skills borrowed from other industries insured that stratification by trade would continue despite mechanisation. Evolving trade unionism in the shipyards came to be based almost entirely on the division of crafts, and not upon a distinctive "industrial" or general consciousness. The shipwrights' societies were traditional craft unions, jealous of their prerogatives and determined to exclude outsiders from their ranks. As a result, when men with different skills entered the yards they could not associate themselves with unions which were already active in shipbuilding. In order to obtain representation, the new trades had either to form societies of their own or join ones which had been set up earlier to represent their trades in other fields of manufacturing or construction.

The shipwrights began to consolidate their various local unions in the 1850's with the formation of the United Kingdom Amalgamated Society of Shipwrights. It had no central funds, and the local unions continued to act independently until the mid-1880's when its loose organization was finally shown to be inadequate. It was then superseded by the much stronger Associated Shipwrights' Society, which guaranteed the right of its members to work in all ports and provided strict centralised control. By 1897 all but three of the local unions had been absorbed, and after the turn of the century, when drillers and some iron shipbuilders had been admitted and the shipwrights in the government dockyards assimilated, the name was changed to the Shipconstructive and Shipwrights' Association. ${ }^{2}$

A second great union in the shipyards was the Amalgamated Society of Engineers. Like the shipwrights, mechanics and engineers had formed local societies throughout the kingdom in the early years of the nineteenth century. Generally the various branches of the trade were represented in different unions, which joined together to conduct strikes. Early national unions included the Steam-Engine Makers

1 Evidence before the Royal Commission on Trade Unions, ibid., q. 17,165.

${ }^{2}$ H. A. Clegg, Alan Fox and A. F. Thompson, A History of British Trade Unions since 1889, I (Oxford, 1964), pp. 132, 443. 
(organised in 1824); the Journeymen Steam-Engine and Machine Makers and Millwrights (1826); the Associated Fraternity of Iron Forgers, usually known as the "Old Smiths" (1830); and the United Society of Boilermakers (1834). ${ }^{1}$

The Amalgamated Society of Engineers was formed in 1851 from a merger of the London and provincial societies led by the Journeymen Steam-Engine and Machine Makers and Millwrights' Friendly Society. Most of the engineering unions affiliated but a few important ones, including the Boilermakers and the Steam-Engine Makers, remained aloof. The membership of the ASE included blacksmiths, fitters, turners, pattern makers, millwrights, planers, borers, slotters, mechanical draftsmen, brass finishers, coppersmiths employed in the engineering trades, machine joiners employed in the construction of cotton, silk, flax, woolen and other machinery, and ships' smiths. ${ }^{2}$

The United Society of Boilermakers and Iron and Steel Ship Builders was founded in Manchester in 1834. Over the years local societies were absorbed, and the union began to admit less skilled men in order to prevent blacklegging. In 1864 the Holders-up Society of Liverpool was recognized but not assimilated. A decade later locals were allowed to accept caulkers at their own discretion, and in 1881 the shipwrights of William Denny and Brothers of Dumbarton and those in Sunderland who had been performing iron work were admitted. The following year the holders-up were accepted but with lower dues and benefits, and in 1892 the Scottish holders-up joined. Light plate workers were absorbed in 1896, and for several years the leadership urged the assimilation of the drillers rather than allow them to remain as potential enemies. The local branches rejected the recommendation, however, and in 1900 the National Society of Drillers and the United Society of Drillers merged with the Shipwrights. ${ }^{3}$

By the 1890's there was a multitude of unions operating in the shipyards. Between 1892 and 1896, 130 "general" shipbuilding unions were in existence, not including the societies of engineers, carpenters, joiners, plumbers and other trades which were active in other industries as well. In addition, there were seven unions of riggers and seventeen of sailmakers, most of which were confined to one port. In the period between 1906 and 1910, the number of general shipbuilding unions

${ }^{1}$ Sidney and Beatrice Webb, The History of Trade Unionism (London, 1920), pp. 204-15.

2 Ibid.; evidence before the Royal Commission on Labour, q. 22,655.

3 D. C. Cummings, History of the United Society of Boilermakers and Iron and Steel Ship Builders (Newcastle-upon-Tyne, 1904), pp. 13, 111-12, 147; J. E. Mortimer, History of the Boilermakers' Society, I (London, 1973), pp. 43, 109-10, 119, 134, 159; Clegg, Fox and Thompson, op. cit., p. 132; Pollard, "The Economic History of British Shipbuilding", pp. 162-63. 
was reduced to 18 , while the riggers and sailmakers had consolidated into five societies. Fragmentation remained common, however, and at times a trade was represented by more than one union in the same yard. ${ }^{1}$

As Allyn Young has pointed out, "the economies of roundabout methods, even more than the economies of other forms of the division of labour, depend upon the extent of the market". ${ }^{2}$ Since most vessels were custom-built, there was little scope for techniques of mass production, making it possible for tradesmen to retain their identities as skilled workers even though they were employed as wage labourers in large concerns. Although the proportion of unskilled labourers did increase, especially after the turn of the century, large-scale mechanisation of work processes was not feasible and most of the workforce remained differentiated into a large number of skilled trades. It is possible, in fact, that between 1870 and 1900 the greater complexity of vessels led to increases in the contribution of skilled labour to the shipbuilding process. Whereas in 1873 hand labour accounted for 24 per cent of the cost of a hull, by 1887 the proportion had risen to 34.5 per cent for large vessels, and to between 36 and 38 per cent for smaller ones. $^{3}$ Similarly, until approximately 1900 skill differentials in pay increased, suggesting that constructional techniques in the late nineteenth century placed a premium on skill; ${ }^{4}$ and although increased use of capital equipment helped to reduce the importance of skilled labour somewhat after 1900 , much of the machinery introduced was intended to enhance the productivity of existing trades rather than to displace them. ${ }^{5}$

The composition of the industry's labour force is difficult to ascertain. With the introduction of iron, the importance of the shipwrights definitely declined and the proportion of unskilled labourers grew. By 1868,35 per cent of the workers in the shipyards of the Thames Iron Works were "unskilled" and 50 per cent of the iron shipbuilders in Scotland were "labourers", but the definition of terms is unclear. At

1 Ninth Report by the Chief Correspondent of the Board of Trade on Trade Unions, 1896 [Cd 8644] (1897), pp. 38-45; Report on Trade Unions in 1908-1910 [Cd 6109] (1912), pp. 16-19.

2 "Increasing Returns and Economic Progress", in : Economic Journal, XXXVIII (1928), p. 531.

3 Transactions of the North East Coast Institution of Engineers and Shipbuilders, V (1888-89), pp. 46-48.

As an indication, see the unique unpublished data on wages and earnings given in Paul L. Robertson, "The Management of Manpower in British Shipbuilding 1870-1914: A Study in the Organization of Human Resources under Conditions of Changing Technology" (unpublished Ph.D. thesis, University of Wisconsin, Madison, 1972), pp. 200-04.

5 Ibid., pp. 90-91. 
that time, payments to joiners, carpenters and painters accounted for about half of the wages on an iron ship. In 1892, 58 per cent of the workforce in eight yards in England and 66 per cent of those in six yards in Scotland were regarded as skilled. Pollard estimates that between 1870 and 1900 the proportion of unskilled workers remained at a fairly constant 20 per cent, but increased with the adoption of machinery after the turn of the century. The increase would have been to some extent offset, however, by a tendency over time to grant skilled status to drillers, turners and other machine operatives who were once considered to be unskilled or at most semi-skilled. ${ }^{1}$

\section{III}

There are two factors which usually suffice to distinguish one trade from another - the nature of the materials worked and the types of tools used. In the middle of the nineteenth century, for example, engineers worked on cold metal with hammers, files and lathes, while boilermakers handled hot iron to rivet hull plates, bend angle irons and perform similar tasks. ${ }^{2}$ As long as technical improvements fell within the province of only one trade, there were few problems. The craft system of organization became increasingly anomalous in the decade before 1914, however, with the development of equipment which could be used by several trades, and of unspecialised machines designed to perform several activities without regard for craft boundaries.

The problem of reorganising labour inputs to suit the needs of changing technology was accentuated by the mood of the unions. Not only had they inherited a guild outlook on the need to restrict entry to the trades, but they were immediately alarmed by the periodic unemployment ${ }^{3}$ and by what they early perceived as a growth in the stock of labour relative to the demand. ${ }^{4}$ Under the circumstances, job security became the paramount concern ${ }^{5}$ and each union was bound to resist changes which might result in the loss of opportunities for

1 Evidence before the Royal Commission on Trade Unions, qq. 17,167, 17,212, 17,363-64; Hobsbawm, op. cit., p. 305, note 40; Pollard, "The Economic History of British Shipbuilding", pp. 140-41.

2 Roberts, op. cit., ch. 2; evidence before the Royal Commission on Trade Unions, q. 16,852.

3 For example, see the fluctuations in employment at the large shipbuilding yard of William Denny and Brothers at Dumbarton, given in Robertson, op. cit., table XVII, pp. 193-94.

4 Phelps Brown, op. cit., p. 102.

5 The attention given to protecting job security is illustrated by the fact that witnesses before the Royal Commission on Labour in 1892 were more concerned with matters of apprenticeship, hours and demarcation than with wages. 
its members. As the Preface to the Rules of the Amalgamated Society of Engineers stated, "It is our duty to exercise the same care and watchfullness over that in which we have a vested interest as the physician does who holds a diploma, or the author who is protected by a copyright." 1 Every technical change which disturbed the existing structure of trades and seemed to give one craft an advantage over another was greeted by a jurisdictional or demarcation dispute in which the unions fought each other for work. Because unions were strongly organised, it was awkward for management to interfere. As a consequence both increased mechanisation and efficient labour allocation became more difficult than might have been the case if the industry had not been organised so closely along craft lines.

Demarcation disputes were common even before iron was adopted, ${ }^{2}$ and they grew in importance as the number of trades multiplied. Some disputes, such as those between platers and their helpers, were products of the gang and contract system. Others, including attempts by the Engineers to destroy the Steam-Engine Makers and the United Pattern Makers as independent societies, were examples of what might be termed trade-union imperialism. There were even cases in which members of the same union, the Boilermakers, fought each other. Most disputes, however, were the result of changes in shipping or shipbuilding technology which created tasks which could either be performed by two or more crafts or could involve entirely new machinery. Traditionally, for example, joiners were confined to wood of $1 \frac{1}{2}$ inches or less in thickness, and used hammers and planes. Shipwrights performed heavier woodwork with adzes and mallets. Both types of tools, along with machines which were unknown when the trades had developed, were necessary to complete the decks of modern passenger ships, hence joiners and shipwrights both claimed the "right" to do the work. Logically, neither side was right or wrong. Since both trades were essential in other stages of construction, however, the employers were powerless to divide the work without arranging a compromise acceptable to both unions. Any arbitrary decision could lead to a strike which might cripple the entire yard. ${ }^{3}$

Similar disputes arose between the fitters, who were members of the Amalgamated Society of Engineers, and the plumbers over the joining of iron, copper and brass pipes, particularly on warships built

1 Quoted in Webb, Industrial Democracy, p. 514.

2 A dispute between caulkers and shipwrights was reported in 1825 , for instance. Evidence before the Select Committee on Combination Laws, 1825, p. 185.

2 Evidence before the Royal Commission on Labour, ibid., qq. 20,448-57; 26,051-52, 26,284, 26,419-21; Clegg, Fox and Thompson, op. cit., p. 131; Cummings, op. cit., p. 111; Webb, Industrial Democracy, pp. 516-18. 
in private yards. All sanitary plumbing and work with lead pipes was conceded to the plumbers, as was the work with iron gas pipes with threaded joints which plumbers had first performed in house building. When plumbers began to form flanged joints on larger iron and copper pipes, however, the fitters complained that their traditional sector was being encroached upon. Iron piping was both cheaper and stronger than lead, and as its use increased the dispute intensified. Work on the iron pipes for ventilation, flooding of compartments, drainage and servicing the thermostats on warships was contested on grounds of custom or precedent, the size of the pipes or the types of joints. The strapping of the tubes was claimed by the smiths as well, and the problem was further complicated by the evolution of different practices in different yards where work was often allotted to either trade depending on how busy each was at the time. It is indicative of the inability of the builders to secure a lasting solution that the issue was still being fought in 1913 much as it had been twenty years earlier. ${ }^{1}$

Disputes could arise wherever the work of one trade bordered on that of another. The engineers quarrelled with the boilermakers, shipwrights, joiners, brassworkers and tinplate workers; the boilermakers with the shipwrights, smiths, chippers and drillers; the shipwrights with the caulkers, boat and barge builders, mast and block makers, and joiners; and the joiners with the millsawyers, pattern makers, cabinetmakers, upholsterers and French polishers. On the Tyne, there was an average of one major strike per month over questions of demarcation between 1890 and $1893 .^{2}$

\section{IV}

Strikes caused by disagreements over jurisdiction were costly. Since losses were suffered by the unions involved, by employers and by the men in other trades who were thrown out of work when yards were closed down, the incentives to find peaceful means of settlement were great. In the early years, there were attempts to avoid disputes through inter-union agreements, but they generally worked for only short periods if at all. In 1865, for example, the joiners and shipwrights on the Clyde drew up a list of work to be performed by each trade in accordance with the custom on the river at that time. The agreement was followed for a few years, but dissolved when the practice of the firms began to change. ${ }^{3}$

1 Evidence before the Royal Commission on Labour, q. 26,284; Fairplay, May 15, 1913, p. 768.

2 Webb, Industrial Democracy, pp. 509, 513.

8 Evidence before the Royal Commission on Labour, qq. 21,434-37. 
After 1880, unions and employers turned to more formal conciliation and arbitration to settle disputes. In 1883 a court of conciliation was established by builders and unions on the Wear. Although not originally intended to deal with matters of demarcation, the court functioned well for several years and was instrumental in settling a dispute between the shipwrights and joiners. Panels established to settle two conflicts on the Tyne were less successful. When in 1890 the joiners and shipwrights could not agree, Thomas Burt, the General Secretary of the Northumberland Miners' Association, was appointed at the suggestion of the joiners to act as an "umpire". After an investigation of over five months, Burt awarded 96 of the 168 items in dispute to the joiners. The latter refused to accept the settlement, however, and struck for fourteen weeks. They complied with the order of a second board to return to work on the basis of Burt's award pending a permanent settlement, but the negotiations dragged on for years. ${ }^{1}$

Also in 1890, the fitters of the Amalgamated Society of Engineers and the plumbers clashed over the allocation of work at the Hebburn shipyard of Robert Stephenson and Company. After a strike by the engineers, an agreement was reached which was to cover all yards on the Tyne, but the wording was contested at Palmer's yard at Jarrow. A second strike followed, and the yard owners along the river locked out the Engineers to compel them to settle. A conciliation board composed of the representatives of the plumbers, Engineers and employers was formed; the Engineers complained that the chairman was prejudiced, however, and withdrew. The board, comprised of a rump of only the plumbers and employers, then issued an award which the Engineers rejected. A third strike and second lock-out took place before a satisfactory compromise was reached. ${ }^{2}$

Both unions and employers tried to create permanent mechanisms to settle disputes before either side struck. The rules of the Federation of Engineering and Shipbuilding Trades, founded in 1890, provided that

"If any dispute takes place between any of the societies forming this Federation, unless amicably settled, such dispute shall be referred to a court of arbitration selected by the parties affected by the dispute. When a court of arbitration is required each party to the dispute shall appoint one or two arbitrators, all of whom must be trade unionists. The two or four arbitrators to appoint an umpire. Failing the arbitrators to agree his decision shall be final

1 Evidence ibid., qq. 26,037, 26,056, 21,438-45; Webb, Industrial Democracy, pp. 510-12.

2 Evidence ibid., qq. 23,081-92, 23,140-48, 23,343-67. 
and binding. The court when formed to decide as to place of meeting, method of procedure, \&c.; each party to pay half of the expenses, unless otherwise ordered by the court." 1

As with other methods of arbitration which were tried, the courts of the Federation failed because in practice there was no way to force either side to accept an agreement which it felt to be unjust.

When the trades proved unable to settle conflicts between themselves, the employers, who had long claimed the right to decide, obliged the unions to accept the concept of local boards of conciliation. By 1900, seven local boards were in existence in the Tyne and Tees Districts, at Middlesbrough, at Birkenhead and on the Clyde. Courts of arbitration similar to those of the Trades Federation were formed with an independent chairman, who could issue a morally-binding award in case of deadlock. Because of the problem of different customs of work on the various rivers, local boards continued to be the primary tribunals down to 1914, and the otherwise comprehensive national agreement of 1909 between the Shipbuilding Employers' Federation and the Shipyard Trade Unions explicitly delegated any questions of demarcation to the local bodies. Nevertheless, they were unsuccessful in providing a lasting framework for compulsory and binding arbitration. By 1911, the shipping journal Fairplay was asking why some means could not be found to eliminate demarcation disputes altogether "by a joint tribunal of all trade unions concerned, with the employers in co-operation", and the following year an official of the Boilermakers Union pronounced the Tyne Demarcation Agreement to be "atrophied". 2 The reasons for the failure of conciliation boards and courts of arbitration to cope with all types of industrial strife are perhaps best summed up by Ernest Aves's remark of 1897:

"The experience of the [engineering] dispute has afforded yet another illustration of the impossibility of having recourse to any

1 Evidence ibid., q. 21,453.

2 Report on the Strikes and Lockouts of 1900 [Cd 689] (1901), p. liii; evidence before the Royal Commission on Labour, qq. 26,132, 26,287-89; evidence before the Industrial Council Inquiry into Industrial Agreements [Cd 6953] (1913), qq. 2,819-21, 3,556; ibid., Appendix V, p. 589; Fairplay, November 16, 1911, p. 696 . The rules of the following boards and committees all provided that no evidence from other areas could be admitted concerning work already performed in the ports: the Tyne Shipbuilding Demarcation Board; the Tees and Hartlepool Joint Committee and Board of Referees for the Demarcation of Work of Various Trades; the Shipwrigths', Joiners' and Employers' Board for Demarcation of Work in Connection with the Associated Yards at the Hartlepools, Stockton and Middlesbrough. Second Report on Rules on Voluntary Conciliation and Arbitration Boards and Joint Committees [Cd 5346] (1910), p. 196, 199, 202. 
regulative machinery for the solution of industrial disputes if either party is averse to them or thinks them unnecessary."1

Despite their notoriety, it is difficult to find a crime, much less a villain, in the story of shipyard demarcation disputes. Irresponsible and even irrational as the disputes may appear, from the standpoint of the workers they were necessary. In an era of endemic unemployment brought on by fluctuations in trade, job security was certainly a legitimate goal. Demarcation quarrels may be viewed as essentially an investment in the future, in which unions forsook current employment by striking to protect themselves against incursions by other trades and, if possible, to gain the greater part of any new work which changing technology might bring along. Nor is it wholly correct to say that the interests of the employers were "remorselessly sacrificed". ${ }^{2}$ Workers as well as employers recognized that some alterations in organisation were necessary to accommodate changes in shipping and shipbuilding technology if Britain were to retain the pre-eminent position in the industry of which both groups were so proud. Ways were found of adjusting to each shift in routine. Demarcation disputes were definitely annoying and, in the short run at least, costly to yard owners, but there is little evidence that this, or any other form of union activity, retarded technical change or the rate of growth of the industry.

1 Ernest Aves, "Labour Notes: The Dispute in the Engineering Trade, \&c.", in: Economic Journal, VII (1897), pp. 630.

2 Evidence before the Royal Commission on Labour, q. 26,284. 